See discussions, stats, and author profiles for this publication at: https://www.researchgate.net/publication/266742622

\title{
26. Valdeyernos, Toledo Mountains (central Spain)
}

Article in Grana · October 2014

DOI: 10.1080/00173134.2014.936490

\section{CITATIONS}

3 authors, including:

Miriam Dorado-Valiño

-.-

44 PUBLICATIONS 758 CITATIONS

SEE PROFILE
READS

78

José Antonio López-Sáez
Spanish National Research Council

534 PUblications 7,424 Citations

SEE PROFILE

Some of the authors of this publication are also working on these related projects:

The Hinojos Project View project

The prehistoric ceremony center of Castillejo del Bonete: one of the most important archaeological discoveries of the 21st century // El centro ceremonial prehistórico de Castillejo del Bonete: uno de los descubrimientos arqueológicos más importantes del siglo XXI. View project 


\section{PROOF COVER SHEET}

Journal acronym: SGRA

Author(s): $\quad$ Miriam Dorado-Valiño, José Antonio López-Sáez and Enrique García-Gómez

Article title: $\quad 26$. Valdeyernos, Toledo Mountains (central Spain)

Article no: $\quad 936490$

Enclosures: $\quad$ 1) Query sheet

2) Article proofs

Dear Author,

1. Please check these proofs carefully. It is the responsibility of the corresponding author to check these and approve or amend them. A second proof is not normally provided. Taylor \& Francis cannot be held responsible for uncorrected errors, even if introduced during the production process. Once your corrections have been added to the article, it will be considered ready for publication.

Please limit changes at this stage to the correction of errors. You should not make trivial changes, improve prose style, add new material, or delete existing material at this stage. You may be charged if your corrections are excessive (we would not expect corrections to exceed 30 changes).

For detailed guidance on how to check your proofs, please paste this address into a new browser window: http://journalauthors.tandf.co.uk/production/checkingproofs.asp

Your PDF proof file has been enabled so that you can comment on the proof directly using Adobe Acrobat. If you wish to do this, please save the file to your hard disk first. For further information on marking corrections using Acrobat, please paste this address into a new browser window:

http://journalauthors.tandf.co.uk/production/acrobat.asp

2. Please review the table of contributors below and confirm that the first and last names are structured correctly and that the authors are listed in the correct order of contribution. This check is to ensure that your name will appear correctly online and when the article is indexed.

\begin{tabular}{|l|l|l|l|l|}
\hline Sequence & Prefix & Given name(s) & Surname & Suffix \\
\hline 1 & & Miriam & Dorado-Valiño & \\
\hline 2 & & José Antonio & López-Sáez & \\
\hline 3 & & Enrique & García-Gómez & \\
\hline
\end{tabular}


Queries are marked in the margins of the proofs, and you can also click the hyperlinks below.

\section{AUTHOR QUERIES}

\section{General points:}

1. Permissions: You have warranted that you have secured the necessary written permission from the appropriate copyright owner for the reproduction of any text, illustration, or other material in your article. Please see http://journalauthors.tandf.co.uk/permissions/usingThirdPartyMaterial.asp.

2. Third-party content: If there is third-party content in your article, please check that the rightsholder details for re-use are shown correctly.

3. Affiliation: The corresponding author is responsible for ensuring that address and email details are correct for all the co-authors. Affiliations given in the article should be the affiliation at the time the research was conducted. Please see http://journalauthors.tandf.co.uk/preparation/writing.asp.

4. Funding: Was your research for this article funded by a funding agency? If so, please insert 'This work was supported by <insert the name of the funding agency in full>', followed by the grant number in square brackets '[grant number $\mathrm{xxxx}$ ]'.

5. Supplemental data and underlying research materials: Do you wish to include the location of the underlying research materials (e.g. data, samples or models) for your article? If so, please insert this sentence before the reference section: 'The underlying research materials for this article can be accessed at <full link> / description of location [author to complete]'. If your article includes supplemental data, the link will also be provided in this paragraph. See $<$ http://journalauthors.tandf.co.uk/preparation/multimedia.asp $>$ for further explanation of supplemental data and underlying research materials.

6. The CrossRef database (www.crossref.org/) has been used to validate the references. Mismatches will have resulted in a query.

AQ1 Please provide missing page numbers for the "Dorado-Valiño et al., 2014" references list entry.

AQ2 Please confirm NPPs as non-pollen palynomorphs, abbreviated in figure. 


\section{How to make corrections to your proofs using Adobe Acrobat/Reader}

Taylor \& Francis offers you a choice of options to help you make corrections to your proofs. Your PDF proof file has been enabled so that you can edit the proof directly using Adobe Acrobat/Reader. This is the simplest and best way for you to ensure that your corrections will be incorporated. If you wish to do this, please follow these instructions:

1. Save the file to your hard disk.

2. Check which version of Adobe Acrobat/Reader you have on your computer. You can do this by clicking on the "Help" tab, and then "About".

If Adobe Reader is not installed, you can get the latest version free from http://get.adobe.com/reader/.

3. If you have Adobe Acrobat/Reader 10 or a later version, click on the "Comment" link at the right-hand side to view the Comments pane.

4. You can then select any text and mark it up for deletion or replacement, or insert new text as needed. Please note that these will clearly be displayed in the Comments pane and secondary annotation is not needed to draw attention to your corrections. If you need to include new sections of text, it is also possible to add a comment to the proofs. To do this, use the Sticky Note tool in the task bar. Please also see our FAQs here:

http://journalauthors.tandf.co.uk/production/index.asp.

5. Make sure that you save the file when you close the document before uploading it to CATS using the "Upload File" button on the online correction form. If you have more than one file, please zip them together and then upload the zip file.

If you prefer, you can make your corrections using the CATS online correction form.

\section{Troubleshooting}

Acrobat help: http:/helpx.adobe.com/acrobat.html

Reader help: http://helpx.adobe.com/reader.html

Please note that full user guides for earlier versions of these programs are available from the Adobe Help pages by clicking on the link "Previous versions" under the "Help and tutorials" heading from the relevant link above. Commenting functionality is available from Adobe Reader 8.0 onwards and from Adobe Acrobat 7.0 onwards.

Firefox users: Firefox's inbuilt PDF Viewer is set to the default; please see the following for instructions on how to use this and download the PDF to your hard drive: http://support.mozilla.org/en-US/kb/view-pdf-files-firefox-without-downloading-them\#w_using-a-pdf-readerplugin 


\section{Valdeyernos, Toledo Mountains (central Spain)}

\section{MIRIAM DORADO-VALIÑO ${ }^{1}$, JOSÉ ANTONIO LÓPEZ-SÁEZ ${ }^{1}$ \& ENRIQUE GARCÍA-GÓMEZ ${ }^{2}$}

$5 \quad{ }^{1}$ Center of Human and Social Sciences, Spanish Council for Scientific Research, Madrid, Spain, ${ }^{2}$ Servicio de Medio Ambiente, Diputación de Toledo, Toledo, Spain

\section{Site details}

Valdeyernos bog $\left(39^{\circ} 26^{\prime} 28^{\prime \prime} \mathrm{N}, 4^{\circ} 05^{\prime} 47^{\prime \prime} \mathrm{W} ; 850 \mathrm{~m}\right.$ above sea level (a.s.1.)) lies on the southern slope of the

10 'Sierra de Torneros' in the central part of the Toledo Mountains (Quintos de Mora Farm, Guadalerzas district, Los Yébenes, Toledo). The peat-bog extends over an area of 3.93 ha and it is a 'special protected habitat' in accordance with Law 9/1999 of Castilla-La

15 Mancha on Nature Conservation. It was designated an 'environmental micro-reserve' in 2003 by the Decree 319/2003 (Martín-Herrero et al. 2004). The area experiences a Mediterranean climate with dry and warm summers, influenced by Atlantic winds from the southwest. The average annual temperature is $14-15{ }^{\circ} \mathrm{C}$ and the annual precipitation is 600 $700 \mathrm{~mm}$. The precipitation is irregular over the year with maximum values during winter (Perea \& Perea 2008). The vegetation of the area is typically Mediterranean, a mixed forest of deciduous oaks Quercus pyrenaica Willd. and Q. faginea subsp. broteroi (Cout.) A.Camus, accompanied by Acer monspessulanum L., Arbutus unedo L., Q. ilex subsp. ballota (Desf.) Samp., Sorbus torminalis (L.), Crataegus monogyna 30 Jacq., Phillyrea angustifolia L., Erica arborea L., E. scoparia L. and Cistus populifolius L. (Gómez-Manzaneque 1988; Baonza et al. 2010). The bog vegetation is composed mainly of Sphagnum palustre L., Drosera rotundifolia L., Pinguicula lusitanica L., E. tetralix L., Calluna vulgaris (L.) Hull and Molinia caerulea (L.) Moench (Velasco 1980; Martín-Herrero et al. 2004). The bedrock is an old siliceous basement made up mainly of sandstones, lutites and quartzites of Early Ordovician age (Muñoz-Jiménez 1976).

\section{Sediment description}

The profile is $50 \mathrm{~cm}$ deep and was collected from the central part of the bog in June 2006 by the last two authors using a Russian corer $5 \mathrm{~cm}$ in diameter. The composition was as follows:

0-14 cm: dark brown, partly decomposed Sphagnum-Cyperaceae peat with sand and gravels > $1 \mathrm{~mm}$ (Th2 Gmin3 Gmaj+ Dh1-10 YR 2/1) 14-34 cm: dark brown, decomposed SphagnumCyperaceae peat with herbaceous and rather numerous wood fragments (Th2 Dh2 D11-10 YR 2/1)

34-50 cm: grey to olive silt with sand and gravels $>1 \mathrm{~mm}$ and macro-charcoal fragments (34-36, 39-43, 46$48 \mathrm{~cm}$ ) (Ld1 Dh1 Dg1 Dl1 Gmaj2-5 YR 3/2)

\section{Dating}

Accelerator mass spectrometry (AMS) carbon-14 $\left({ }^{14} \mathrm{C}\right)$ dating was performed on bulk peat samples by the 'Centro Nacional de Aceleradores' (CNA, CSIC) in Sevilla (Spain). The calibration ( $2 \sigma$ range) was performed using CALIB 6.0. and CALIBomb (with the calibration dataset $\mathrm{NH}$ zone 1) software (Stuiver \& Reimer 1993; Hua \& Barbetti 2004). Calibrated radiocarbon dates are given as cal $\mathrm{BC}$ or cal AD. Dating results are as follows:

14-15 cm: CNA 717, pM 101.27 \pm 0.26 ( $\mathrm{cal} \mathrm{AD}$ 1953-1956)

29-30 cm: CNA 719, $95 \pm 30$ вр (cal AD 1683-1930) $40 \mathrm{~cm}$ : CNA 718, $515 \pm 30$ BP (cal AD 1326-1444) $48-50 \mathrm{~cm}:$ CNA 093, $2935 \pm 33$ вр (1261-1027 cal вС)

Correspondence: Miriam Dorado-Valiño, CSIC - CCHS, Albasanz 26-28, Madrid 28037, Spain. E-mail: doradomiriam@hotmail.com 


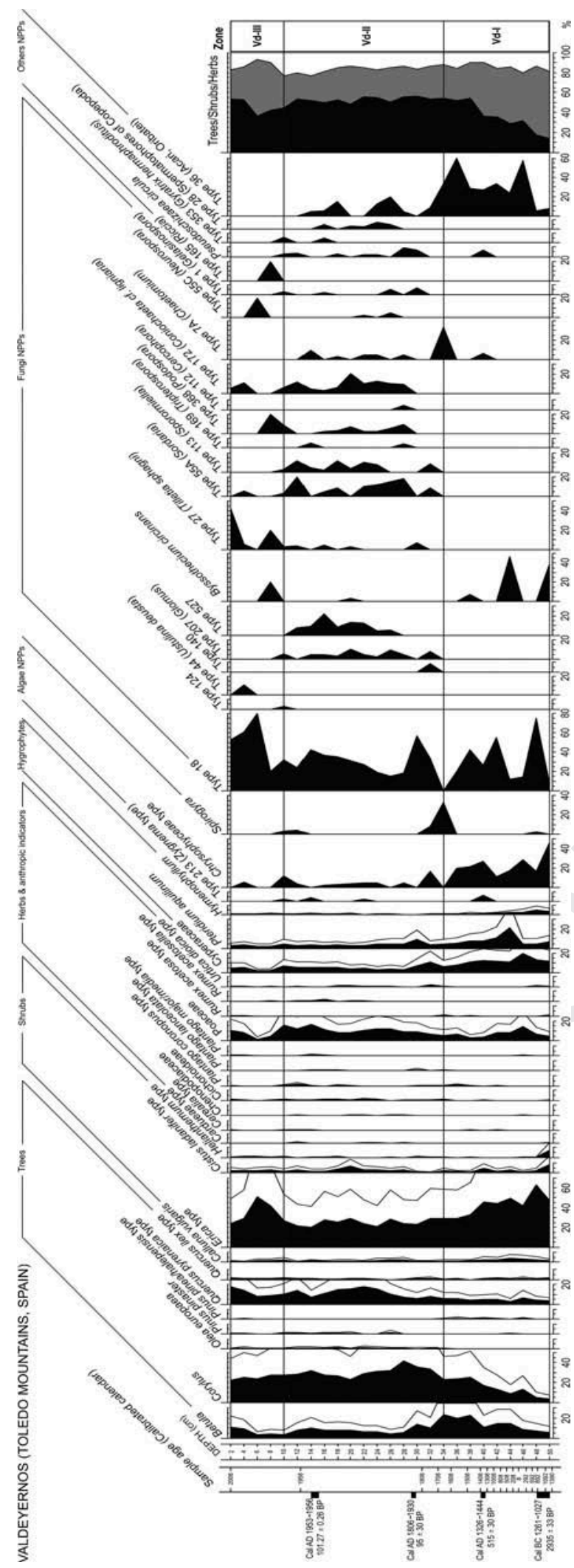

Figure 1. Pollen diagram from Valdeyernos bog (Toledo Mountains, central Spain). Selected pollen, spores of ferns and non-pollen palynomorphs (NPPs) taxa are represented. Hollow curves are exaggerated $2 \times$.
Percent Modern $(\mathrm{pM})$ is used to describe radiocarbon measurements for the past 45 years (http://www. radiocarbon.com/PDF/Beta-AMS-Methodology.pdf)

\section{Interpretation}

The core was sampled at $2 \mathrm{~cm}$ intervals. More than 500 terrestrial pollen grains were identified in each sample. The pollen sum $(100 \%)$ includes all pollen grains except for hygrophytes and aquatic plants, spores of ferns and non-pollen palynomorphs (Figure 1). The arboreal vegetation comprised Betula, Corylus and both deciduous and evergreen Quercus throughout the entire sequence. This vegetation was quite different from the close by Patateros bog (Dorado-Valiño et al. 2014), where the arboreal vegetation is scarce during the same time period. The differences between the two pollen records could be due to fact that the Patateros bog is located on a northern slope and the Valdeyernos bog on a southern slope. Therefore, the Valdeyernos site was more affected by south-western Atlantic warm and humid winds than the Papateres, site; the Valdeyernos bog is, furthermore, located in a little valley where drain streams lead to high edaphic humidity. Four pollen assemblage zones were defined using CONISS in TILIA ${ }^{\circledR}$ and TILIA-GRAPH ${ }^{\circledR}$ (Eric C. Grimm) computer programs:

\section{VD-I (50-40 cm; c. $1300 \mathrm{cal} \mathrm{BC-cal} \mathrm{AD} \mathrm{1420)}$}

The landscape is dominated by a shrub community composed of Erica-type accompanied by Cistus ladanifer-type, Helianthemum-type, Calluna vulgaris and Poaceae. The high values of Erica-type pollen could be an overrepresentation of local species as the bog is large. This vegetation also contained isolated stands of Betula, Corylus and both deciduous and evergreen Quercus with an undergrowth of ferns (Pteridium aquilinum (L.) Kuhn, Hymenophyllum). The presence of hygrophytes (Cyperaceae), freshwater algae (Chrysophyceae, Spirogyra) and ascospores of HdV-18 and Byssothecium circinans Fuckel suggests moist conditions and relatively high water tables (Van Geel \& Aptroot 2006). The maximum percentage of $\mathrm{HdV}-18(48 \mathrm{~cm})$ can be correlated with the onset of the so-called $2.8 \mathrm{ka}$ cal BP event $(c$. 850-760 cal BC; Van Geel et al. 1998), while minimum values (46-44 cm, c. $230 \mathrm{cal} \mathrm{BC-cal} \mathrm{AD} \mathrm{275)} \mathrm{with} \mathrm{an} \mathrm{arid}$ interval described in the Iberian Peninsula at this time (Martin-Puertas et al. 2008).

\section{VD-II (40-34 cm; c. cal AD 1420-1665)}

In this pollen zone, the previous landscape progressively changed to a vegetation dominated by Betula, Corylus and deciduous Quercus, although heathers are still abundant. The chronological boundaries of this zone 
correlate well with the onset of the Little Ice Age, which, in Spain, was a cold interval with an initial dry phase, until cal $\mathrm{AD} 1550$, and a later more humid one until the recent present (Manrique \& Fernández-Cancio 2000). Towards the end of the pollen zone, a maximum of Chaetomium is detected coinciding with a level of macro-charcoals and the appearance of Olea europaea $\mathrm{L}$.

\section{VD-III (34-10 cm; c. cal AD 1665-1970)}

Groups of birch and hazel were distributed along the periphery of the bog, while the slopes of the surrounding hills were covered by mixed oak forests (probably

130 Quercus pyrenaica and Q. faginea). Olea europaea and evergreen Quercus are scarcely represented. The presence of Pinus pinaster Aiton pollen during the last century (the uppermost $28 \mathrm{~cm}$ ) was contributed by planted trees (Gómez-Manzaneque 1988). The nonarboreal vegetation is mainly composed of Erica-type and Poaceae with a similar representation of Calluna vulgaris and Cistus ladanifer-type. This pollen zone is characterized by maximum values of dung-related fungal spores (Sordaria, Sporormiella, Cercophora, 140 Podospora, Tripterospora, Coniochaeta), although the values of anthropozoogenous taxa (Chenopodiaceae, Plantago lanceolata-type, Plantago major/Plantago media-type, Urtica dioica-type) are relatively low, suggesting local grazing (López-Sáez \& López-Merino 2007). Weak human impact is suggested by the continuous presence of anthropogenic pollen indicators (Cardueae, Cichorioideae, Rumex acetosella-type). Erosive processes are reflected by the presence of Glomus, Pseudoschizaea circula (Wolff) Christopher and Entorrhiza. The progressive decline of Betula, hygrophytes, freshwater algae and Byssothecium circinans suggests initial drier conditions, which could favour the peat-bog formation at $34 \mathrm{~cm}$, as shown by the sedimentary description and the continuous presence of Tilletia sphagni Navashin. Two maximum peaks for HdV-18 indicate wet phases (Mighall et al. 2006), while minimum values at $34 \mathrm{~cm}$ ( $\mathrm{cal} \mathrm{AD} 1665$ ) and 28-24 cm (cal AD 1873-1895) can be correlated with two severe drought episodes reconstructed from rogation ceremonies recorded at the Toledo Cathedral (Domínguez-Castro et al. 2008).

\section{VD-IV (10-2 cm; c. cal AD 1970-2006)}

The landscape is almost the same as in the previous pollen zone but with a greater representation of Ericatype and a general decrease of coprophilous fungi.

\section{Acknowledgements}

This contribution was financed by Project CGL2011-30512-C02-01 of the R\&D National
Plan of the Spanish Government, by the Technology Research 'Consolider' Programme (TCP-CSD2007-00058), and by the Specific Agreement Diputación de Toledo-CSIC.

\section{References}

Baonza J, Caparrós R, García N, Martínez F, GómezManzaneque F. 2010. Flora vascular de los Quintos de Mora (Los Yébenes, Toledo). Ecología 23: 39-58.

Domínguez-Castro F, Santisteban JI, Barriendos M, Mediavilla R. 2008. Reconstruction of drought episodes for central Spain from rogation ceremonies recorded at the Toledo Cathedral from 1506 to 1900: A methodological approach. Global and Planetary Change 63: 230-242. doi:10.1016/j.gloplacha.2008.06.002.

Dorado-Valiño M, López-Sáez JA, García-Gómez E. 2014. Contributions to the European Pollen Database 21: Patateros, Toledo Mountains (central Spain). Grana 53: $\mathrm{XX}-\mathrm{XX}$.

Gómez-Manzaneque F. 1988. La cubierta vegetal en los Montes de Mora (Los Yébenes, Toledo). Ecología 2: 111-130.

Hua Q, Barbetti M. 2004. Review of tropospheric bomb ${ }^{14} \mathrm{C}$ data for carbon cycle modelling and age calibration purposes. Radiocarbon 46: 1273-1298.

López-Sáez JA, López-Merino L. 2007. Coprophilous fungi as a source of information of anthropic activities during the Prehistory in the Amblés Valley (Ávila, Spain): The archaeopalynological record. Revista Española de Micropaleontología 39: 103-116.

Manrique E, Fernández-Cancio A. 2000. Extreme climatic events in dendroclimatic reconstructions from Spain. Climatic Change 44: 123-138.

Martín-Herrero J, Frontaura MC, Plaza F. 2004. Microrreservas de Castilla-La Mancha. Medio Ambiente en Castilla-La Mancha 11: 1-48.

Martin-Puertas C, Valero-Garees, BL, Mata MP, GenzalezSamperiz, P, Bao R, Moreno A, Stefanova V. 2008. Arid and humid phases in southern Spain during the last 4000 years: The Zoñar lake record, Córdoba. The Holocene 18: 907-921. doi:10.1177/0959683608093533.

Mighall TM, Martínez-Cortizas A, Biester H, Turner SE. 2006. Proxy climate and vegetation changes during the last five millennia in NW Iberia: Pollen and non-pollen palynomorph data from two ombrotrophic peat bogs in the North Western Iberian Peninsula. Review of Palaeobotany and Palynology 141: 203-223. doi:10.1016/j.revpalbo.2006.03.013.

Muñoz-Jiménez J. 1976. Los Montes de Toledo. Estudio de Geofrafía Física. Oviedo: Instituto J.S. Elcano, CSIC and Universidad de Oviedo.

Perea D, Perea R. 2008. Vegetación y flora de los Montes de Toledo. Guía de Campo. Toledo: Covarrubias.

Stuiver M, Reimer PJ. 1993. Extended ${ }^{14} \mathrm{C}$ database and revised CALIB radiocarbon calibration program. Radiocarbon 35: 215-230.

Van Geel B, Aptroot A. 2006. Fossil ascomycetes in Quaternary deposits. Nova Hedwigia 82: 313-329. doi:10.1127/00295035/2006/0082-0313.

Van Geel B, Van der Plicht J, Kilian MR, Klaver ER, Kouwenberg JHM, Renssen H, Reynaud-Farrera L, Waterbolk HT. 1998. The sharp rise of $\Delta^{14} \mathrm{C}$ ca. $800 \mathrm{cal}$ BC: Possible causes, related climatic teleconnections and the impact on human environments. Radiocarbon 40: 535-550.

Velasco A. 1980. Notas sobre los enclaves higroturbosos de los Montes de Toledo (España). Anales del Jardín Botánico de Madrid 37: 125-128. 